\title{
Peningkatan Keterampilan Motorik Kasar Melalui Alat Permainan Simpai Pada Anak Kelompok A di Taman Kanak- Kanak Dharma Wanita Bangun Pungging Mojokerto
}

\author{
Amilatul Zahroh ${ }^{1}$, Yahya Aziz ${ }^{2}, \mathrm{Al}$ Qudus Nofiandri Eko Sucipto Dwijo ${ }^{3}$
}

Received: 01062019 / Accepted: 0106 2019 / Published online: 15062019

(C) 2019 Early Chilhood Islamic Education Study Program

\begin{abstract}
The background of this research is that gross motoric activities in schools are rarely carried out due to the limited facilities and infrastructure owned by the school. The solution to overcome this problem is the application of the hoop game tool. This study aims to determine the application of hulahoop playing tools as an effort to increase gross motor skills in group A children at Dharma Wanita Kindergarten Bangun Pungging Mojokerto. The formulation of the problem in this study include: 1) How to apply the hoop game tool to improve gross motor skills in group A children in Dharma Wanita Kindergarten Bangun Pungging Mojokerto? 2) How to increase gross motor skills through hoop playing tools in group A children at Dharma Wanita Kindergarten Bangun Pungging Mojokerto? This type of research is classroom action research which aims to improve the quality of learning by using the Kemmis \& Taggart spiral model action research. The study was conducted in two cycles. Each cycle is held for three meetings. Each cycle consists of four stages: the planning, implementation, observation and reflection stages. The subjects in this study were children of group A totaling 17 students consisting of 8 male students and 9 female students. Data collection techniques used in this study are interviews, observation and documentation. The results of the study can be explained as follows: 1) the application of the hoop game runs well in Cycle II. This can be seen in the results of observations of teacher activities in Cycle I, namely 80 (good) and in Cycle II it increased to 86.66 (very good). The results of observation of student activities in Cycle I were 75 (good) and in Cycle II it rose to 88.33 (very good). 2) increase in gross motor skills based on the average grade of the 59.70 (sufficient) pre cycle, in the cycle up to 69.70 (enough) and in Cycle II it increased to 91.47 (very good). Whereas gross motor percentage at pre cycle was $23.52 \%$ (Undeveloped), in Cycle I it was 52.94\% (Start developing) and in Cycle II it increased significantly to $88.23 \%$ (Developing Very Good).
\end{abstract}

Keywords: Hulahoop Playing, Gross Motor Skills

Abstrak: Penelitian ini dilator belakangi oleh kegiatan motorik kasar di sekolah yang jarang dilakukan oleh para guru. Hal ini dikarenakan adanya keterbatasan sarana dan prasarana yang dimiliki oleh sekolah. Salah satu Solusi untuk mengatasi masalah tersebut adalah penerapan alat permainan simpai. Rumusan masalah dalam penelitian ini: 1) Bagaimana penerapan alat permainan simpai untuk meningkatkan keterampilan motorik kasar pada anak kelompok A di TK Dharma Wanita Ds. Bangun Kec. Pungging Kab. Mojokerto? 2) Bagaimana

\footnotetext{
${ }^{1}$ UIN Sunan Ampel Surabaya

${ }^{2}$ UIN Sunan Ampel Surabaya

${ }^{3}$ UIN Sunan Ampel Surabaya
} 
peningkatan keterampilan motorik kasar melalui alat permainan simpai pada anak kelompok A di TK Dharma Wanita Ds. Bangun Kec. Pungging Kab. Mojokerto? Jenis penelitian ini merupakan penelitian tindakan kelas (PTK) dengan menggunakan model spiral Kemmis \& Taggart yang dilakukan dalam dua siklus dan masing- masing siklus terdiri dari empat tahap yaitu tahap rencana, pelaksanaan, observasi dan refleksi. Subyek dalam penelitian ini anak kelompok A. Teknik pengumpulan data yang digunakan dalam penelitian ini yaitu wawancara, observasi dan dokumentasi. Hasil penelitian bahwa: 1) penerapan alat permainan simpai berjalan dengan baik pada siklus I dan siklus II. Hal ini dapat dilihat pada hasil observasi aktivitas guru pada siklus I yaitu 80 (baik) dan pada siklus II meningkat menjadi 86,66 (sangat baik). Untuk hasil observasi aktivitas siswa pada siklus I sebesar 75 (baik) dan pada siklus II naik menjadi 88,33 (sangat baik). 2) peningkatan keterampilan motorik kasar berdasarkan nilai rata-rata kelas pada pra siklus 59,70 (cukup), pada siklus naik menjadi 69,70 (cukup) dan pada siklus II meningkat menjadi 91,47 (sangat baik). Sedangkan persentase motorik kasar pada pra siklus sebesar 23,52\% (Belum Berkembang), di Siklus I sebesar 52,94\% (Mulai berkembang) dan pada Siklus II meningkat signifikan menjadi 88,23\% (Berkembang Sangat Baik).

Kata Kunci: Alat Permainan Simpai, Motorik Kasar

\section{PENDAHULUAN}

Undang-Undang Nomor 20 tahun 2003 tentang Sistem Pendidikan Nasional pada Bab 1 Pasal 1 ayat 14 menyatakan bahwa "Pendidikan Anak Usia Dini adalah suatu upaya pembinaan yang ditujukan kepada anak sejak lahir sampai dengan usia 6 tahun yang dilakukan melalui pemberian rangsangan pendidikan utnuk membantu pertumbuhan dan erkembangan jasmani dan rohani agar anak memiliki kesiapan dalam memasuki pendidikan lebih lanjut" (Depdiknas, 2003).

Terdapat enam aspek perkembangan yang dikembangkan dalam pendidikan anak usia dini meliputi:(1) Aspek Nilai-Nilai Agama dan Moral (NAM), (2) Aspek Sosial Emosional (SOSEM), (3) Aspek Kognitif (KOG), (4) Aspek Bahasa (BHS), (5) Aspek Seni dan (6) Aspek Fisik Motorik (FM). Di Taman Kanak-kanak aspek-aspek tersebut dikembangkan melalui pembelajaran sehari-hari.

Dari uraian enam aspek di atas, salah satu aspek perkembangan pada anak yang perlu dikembangkan sejak dini adalah aspek perkembangan fisik motorik. Menurut Hurlock perkembangan fisik motorik merupakan perkembangan gerakan jasmani melalui kegiatan pada pusat syaraf, dan otot.keterampilan motorik terbagi menjadi dua yaitu keterampilan motorik kasar dan keterampilan motorik halus (Hurlock, 1978: 151).

Lingkup perkembangan motorik kasar pada anak usia dini menurut Peraturan Menteri Pendidikan Nasional Republik Indonesia No. 137 Tahun 2014 Pasal 10 Ayat 3 yang tertuang dalam Standar Tingkat Pencapaian Perkembanagan Anak (STPPA) kegiatan fisik motorik kasar mencakup kemampuan gerakan tubuh secara terkoordinasi, lentur, seimbang, lincah, lokomotor, non-lokomotor, dan mengikuti aturan. Di antaranya dengan cara memanfaatkan alat permainan kelas dengan melakukan 
aktivitas fisik seperti melompat, meloncat, melempar, menendang, merangkak dan lainlain.

Berdasarkan hasil wawancara singkat dengan guru kelas TK A pada tanggal 2 Mei 2018, beliau menyadari jika kegiatan pengembangan fisik motorik kasar pada anak jarang dilakukan dikarenakan keterbatasan sarana dan prasarana pada sekolah yang memiliki halaman tidak terlalu luas dan hanya memiliki dua jenis alat permainan (outdoor) yaitu berupa ayunan dan panjatan.

Berdasarkan hasil uraian di atas mengingat kurangnya sarana dan prasarana yang dimiliki sekolah, maka peneliti dan guru sepakat mengembangkan aktivitas motorik kasar dengan menggunakan alat permainan simpai untuk anak kelompok A (usia 45 tahun). Dengan menggunakan alat permainan simpai diharapkan dapat meningkatkan kemampuan motorik kasar anak.

Berdasarkan latar belakang di atas, penulis tertarik melakukan Penelitian Tindakan Kelas (PTK) dengan mengangkat penelitian ini dengan judul "Peningkatan Keterampilan Motorik Kasar Melalui Alat Permainan Simpai Pada Anak Kelompok A Di Taman Kanak-Kanak Dharma Wanita Bangun Pungging Mojokerto".

\section{METODE}

A. Jenis Penelitian

Metode yang digunakan dalam penelitian ini adalah penelitian tindakan kelas (Classroom Action Research) atau lebih dikenal dengan PTK. Kasbolah menjelaskan penelitian tindakan kelas merupakan penelitian dalam bidang pendidikan yang dilakukan dalam kawasan sekolah yang bertujuan untuk memperbaiki serta meningkatkan kualitas pembelajaran (Ningrum, 2014: 22).

Menurut Kemmis dan Robin Mc Taggart (1990) yang dikutip oleh Arifin, (2011: 97-99) mengemukakan bahwa penelitian tindakan kelas bersifat kolaboratif, yakni melibatkan semua orang yang bertanggung jawab untuk meningkatkan mutu pendidikan. Pelaksanaannya dilakukan dalam bentuk spiral mulai dari siklus tahap rencana (planning), pelaksanaan (action), observasi (observation), refleksi (reflection) dan selanjutnya kembali ke rencana. Penelitian tindakan kelas dapat dibuktikan dengan menganalisis, menilai dan menanggapi.

Komponen tersebut dapat dilihat pada bagan siklus di bawah ini.

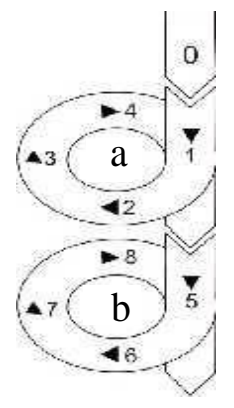

Gambar 1

Siklus PTK menurut Kemmis \& Taggart Model Spiral (Wijaya Kusumah \& Dedi Ditagama, 2011: 21). 


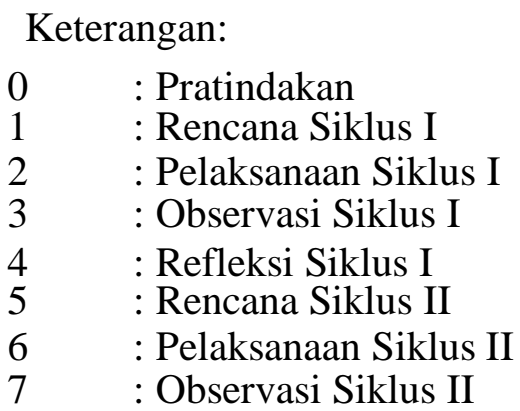

B. Setting Penelitian

1. Subyek Penelitian

Penelitian tindakan kelas ini dilakukan pada siswa kelompok A usia 4-5 tahun di TK Dharma Wanita yang berjumlah 17 siswa. Yang terdiri dari 8 siswa laki-laki dan 9 siswa perempuan.

2. Tempat penelitian

Penelitian ini dilaksanakan di TK Dharma Wanita Desa Bangun Kecamatan Pungging Kabupaten Mojokerto Provinsi Jawa Timur.

3. Waktu penelitian

Penelitian ini dilaksanakan pada semester II yaitu tepatnya pada bulan Mei tahun ajaran 2017/2018.

C. Metode Pengumpulan Data

Data penelitian ini di peroleh melalui observasi, wawancara dan dokumentasi. Data penelitian bersumber pada pencapaian belajar anak yang dihasilkan dari kegiatan motorik melakukan gerak dasar pada anak kelompok A di TK Dharma Wanita.

\section{HASIL PENELITIAN DAN ANALISIS}

\section{A. Deskripsi Lokasi Penelitian}

Penelitian ini dilakukan di TK Dharma Wanita yang terletak di Desa Bangun Kecamatan Pungging Kabupaten Mojokerto. Desa Bangun merupakan sebuah desa yang terletak di perbatasan antara wilayah Mojokerto dengan Sidoarjo. Letak sekolah TK Dharma Wanita berjajaran dengan balai Desa Bangun dan letaknya tergolong strategis dekat dengan pemukiman warga desa setempat. Sarana dan prasarana yang ada di TK Dharma Wanita masih kurang memadai. TK Dharma Wanita memiliki dua ruang kelas, satu ruang kantor guru, dan satu ruang kamar mandi. Fasilitas lain yang dimiliki TK Dharma Wanita yaitu terdapat dua alat permainan outdoor yang terletak dihalaman sekolah. Alat permain outdoor tersebut adalah ayunan dan panjatan melengkung. Sedangkan untuk lat permainan indoor seperti, balok, puzzle, dan buku-buku bacaan tersimpan didalam perpustakaan mini yang berada didalam ruang kantor guru.

TK Dharma Wanita memiliki tenaga pengajar berjumlah 4 orang, terdiri dari 2 orang sebagai guru kelas, 1 orang sebagai guru bantu dan 1 orang kepala sekolah yang merangkap sebagai guru. Peserta didik di TK Dharma Wanita berjumlah 38 anak yang terdiri dari 17 anak kelompok A dan 21 anak kelompok TK B. Dalam penelitian ini, kelas yang akan diberi tindakan adalah kelompok A yang berjumlah 17 anak. 


\section{B. Pembahasan}

1. Penerapan Alat Permainan Simpai Untuk Meningkatkan Keterampilan Motorik Kasar Pada Anak Kelompok A Di TK Dharma Wanita Bangun Pungging Mojokerto

Alat permainan simpai mampu untuk meningkatkan keterampilan motorik kasar pada anak. Melalui alat permainan simpai anak-anak tertarik untuk melakukan kegiatan motorik kasar. Selain itu alat tersebut aman untuk digunakan dan menyenangkan bagi anak- anak.

Penerapan alat permainan simpai dalam penelitian ini terdiri dari lima indikator antara lain 1) berjalan jinjit, 2) melompat menggunakan dua kaki, 3) melompat menggunakan satu kaki, 4) merangkak dalam lingkaran simpai, 5) melompat dalam simpai kemudian mengambil simpai yang lain untuk dilompati.

Penerapan alat permainan simpai untuk meningkatkan keterampilan motorik kasar dalam pembelajaran pada anak kelompok A di TK Dharma Wanita Ds. Bangun Kec. Pungging Kab. Mojokerto dilaksanakan selama dua siklus, setiap siklus dilakukan selama tiga pertemuan. Dalam setiap siklusnya mengalami perbedaan hasil yang signifikan meningkat. Hasil tersebut menegaskan bahwa alat permainan simpai dapat dijadikan salah satu media pembelajaran bagi guru untuk meningkatkan dan mengoptimalkan keterampilan motorik kasar anak.

Hal tersebut dapat dilihat melalui hasil observasi aktivitas guru dan siswa pada Siklus II terjadi peningkatan. pada Siklus I observasi aktivitas guru memperoleh nilai 80 dan pada Siklus II meningkat sebesar 6,66 menjadi 86,66. Observasi aktivitas siswa pada Siklus I mendapat nilai 75 dan pada Siklus II meningkat sebesar 13,33 menjadi 88,33. Peningkatan hasil observasi guru dan siswa pada Siklus II telah memenuhi kriteria indikator kebersihan yang ditentukan yaitu 85 .

\section{Peningkatan Keterampilan Motorik Kasar Melalui Alat Permainan Simpai Pada Anak Kelompok A Di TK Dharma Wanita Bangun Pungging Mojokerto}

Selain dari hasil observasi aktivitas guru dan siswa yang meningkat, hasil penelitian tindakan kelas (PTK) observasi keterampilan motorik kasar dari mulai Pra Siklus, siklus1 dan Siklus II mendapatkan hasil yang signifikan meningkat dalam setiap siklusnya.

Hasil observasi keterampilan motorik kasar pada Pra Siklus nilai rata-rata hasil keterampilan motorik kasar siswa sebesar 59,70 hanya ada 4 siswa yang tuntas sesuai dengan nilai KKM dengan persentase

23,52\% sedangkan yang tidak tuntas berjumlah 13 siswa dengan persentase sebesar 76,48\%. Hasil Pra Siklus menunjukkan bahwa keterampilan motorik kasar pada anak kelompok A sebesar 23,52\% dengan kriteria BB (Belum Berkembang).

Untuk hasil observasi kegiatan motorik kasar dengan menggunakan alat permainan simpai yang dilakukan pada Siklus I diketahui bahwa nilai ratarata hasil keterampilan motorik kasar siswa 69,70. Terdapat 9 siswa yang tuntas sesuai dengan nilai KKM dengan persentase 52,94\% sedangkan yang tidak tuntas berjumlah 8 siswa dengan persentase sebesar 47,05\%. Hasil Siklus I menunjukkan bahwa keterampilan motorik kasar pada anak kelompok A sebesar 52,94\% dengan kriteria MB (Mulai Berkembang). 
Sedangkan, hasil observasi kegiatan motorik kasar dengan menggunakan alat permainan simpai yang dilakukan pada Siklus II diketahui bahwa nilai rata-rata hasil keterampilan motorik kasar siswa 91,47. Terdapat 15 siswa yang tuntas sesuai dengan nilai KKM dengan persentase $88,23 \%$ sedangkan yang tidak tuntas berjumlah 2 siswa dengan persentase sebesar 11,76\%. Hasil Siklus II menunjukkan bahwa keterampilan motorik kasar pada anak kelompok A sebesar 88,23\% dengan kriteria BSB (Berkembang Sangat Baik).

Hasil keterampilan motorik kasar pada pra siklus, siklus I dan siklus II dapat dilihat pada grafik berikut ini.

\section{Grafik 1}

Keterampilan Motorik Kasar Pada Pra Siklus, Siklus I dan Siklus II

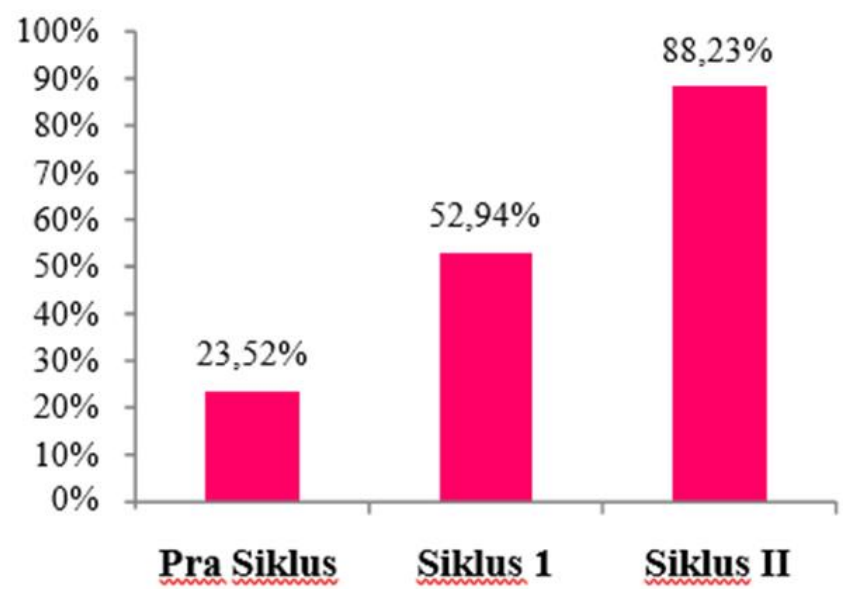

Berdasarkan grafik diatas dapat diketahui bahwa keterampilan motorik kasar pada anak kelompok A Dharma Wanita Desa Bangun dari Pra Siklus, Siklus I, dan Siklus II telah mengalami peningkatan yang signifikan. Pada Pra Siklus sebesar 23,52\% kemudian pada Siklus I naik sebesar $29,42 \%$ menjadi

52,94\%. Dari Siklus I 53\% ke Siklus II terjadi peningkatan sebesar 35,29\% menjadi $88,23 \%$.Dari data tersebut, indikator keberhasilan dalam penelitian tindakan kelas ini yaitu $\geq 85 \%$ telah tercapai pada Siklus II yaitu $88,23 \%$.

Berdasarkan pembahasan di atas dapat disimpulkan bahwa penerapan alat permainan simpai dapat meningkatkan keterampilan motorik kasar pada anak kelompok A di Taman Kanak-kanak Dharma Wanita Bangun Pungging Mojokerto.Hal tersebut dapat dilihat dari beberapa aspek penilaian pada observasi aktivitas guru dan siswa, nilai rata-rata kelas dan persentase keterampilan motorik kasar yang mengalami peningkatan secara sigifikan.

\section{SIMPULAN DAN SARAN}

\section{Simpulan}

Berdasarkan hasil analisis data dan pembahasan dalam penelitian tindakan kelas (PTK) mengenai peningkatan keterampilan motorik kasar melalui alat permainan simpai pada anak kelompok A di TK Dharma Wanita Desa Bangun. Peneliti dapat mengambil kesimpulan sesuai dengan rumusan masalah yang telah diajukan sebagai berikut: 
1. Penerapan alat permainan simpai mampu meningkatkan keterampilan motorik kasar anak kelompok A di TK Dharma Wanita Desa Bangun yang telah dilaksanakan selama dua siklus dan mengalami peningkatan keterampilan motorik kasar pada setiap siklusnya, yang terdiri dari lima indikator antara lain 1) berjalan jinjit, 2) melompat menggunakan dua kaki, 3) melompat menggunakan satu kaki, 4) merangkak dalam lingkaran simpai, 5) melompat dalam simpai kemudian mengambil simpai yang lain untuk dilompati.

2. 2. Keterampilan motorik kasar pada anak kelompok A Dharma Wanita Desa Bangun mengalami peningkatan yang signifikan pada setiap siklusnya. Terlihat dari hasil rata-rata pada Pra Siklus ke Siklus I meningkat sebesar 10 dari 59,7 menjadi 69,7. Pada Siklus I ke Siklus II meningkat sebesar 21,77 dari 69,7 meningkat menjadi 91,47. Persentase keterampilan motorik kasar juga meningkat pada Pra Siklus sebesar 23,52\%. Selanjutnya pada Siklus I mengalami peningkatan sebesar $29,42 \%$ menjadi 52,94\%. Pada Siklus II meningkat sebesar $35,29 \%$ menjadi $88,23 \%$.

\section{AKNOWLEDGMENT}

Peneleitian ini di dukung oleh UIN Sunan Ampel Surabaya.

\section{DAFTAR RUJUKAN}

Depdikbud. (2013). Materi pelatihan guru implementasi kurikulum 2013 SMP, MTs Ilmu Alam (pp.1-366). Jakarta: Badan Pengembangan Sumber Daya Manusia Pendidikan dan Kebudayaandan Penjaminan Mutu Pendidikan, Kemendikbud.

Paramata, Y. (2001). Pengembangan model so-sialisasi inovasi dan supervisi pembelajaran ilmupengetahuan alam. (Disertasi Doktor. Universitas Pendidikan Indonesia).

Subhan, Zaitunah. (2004). Membina Keluarga Sakinah. Yogyakarta: Pustaka Pesantren.

Abdullah, M. Imron. (2003). Pendidikan Keluarga Bagi Anak,. Cirebon: Lektur.

Abdurrahman, Jamal. (2006). Cara Nabi Menyiapakan Generasi. Surabaya: Kreatif Pustaka.

Smith, David. (2012). Sekolah Inklusif: Konsep dan Penerapan Pembelajaran, cet. ke-3

Bandung: Nuansa, 2012 .

Maulidya. Ulfah. (2012). Konsep Dasar PAUD. Bandung: RemajaRosdakarya.

\section{AUTHOR}

Amilatul Zahroh, merupakan Mahasiswa Program Studi Pendidikan Islam Anak Usia Dini UIN Sunan Ampel Surabaya

Yahya Aziz dan Al Qudus Nofiandri Eko Sucipto Dwijo, merupakan Dosen Program Studi Pendidikan Islam Anak Usia Dini UIN Sunan Ampel Surabaya 